NBER WORKING PAPER SERIES

\title{
INTERNET RISING, PRICES FALLING: MEASURING INFLATION IN A WORLD OF E-COMMERCE
}

\author{
Austan D. Goolsbee \\ Peter J. Klenow \\ Working Paper 24649 \\ http://www.nber.org/papers/w24649 \\ NATIONAL BUREAU OF ECONOMIC RESEARCH \\ 1050 Massachusetts Avenue \\ Cambridge, MA 02138 \\ May 2018
}

Mathias Jimenez and Matteo Leombroni provided superb research assistance; Alberto Cavallo, Charles Hulten, and Leonard Nakamura helpful comments; and Luis Maykot and Siddharth Kulkarni assistance in accessing and understanding the Adobe data. Goolsbee thanks the Initiative on Global Markets at the University of Chicago Booth School of Business for financial support. Klenow is grateful to the Stanford Institute for Economic Policy Research for financial support. This is a more expansive version of an AEA Papers and Proceedings paper. The views expressed herein are those of the authors and do not necessarily reflect the views of the National Bureau of Economic Research.

NBER working papers are circulated for discussion and comment purposes. They have not been peer-reviewed or been subject to the review by the NBER Board of Directors that accompanies official NBER publications.

(C) 2018 by Austan D. Goolsbee and Peter J. Klenow. All rights reserved. Short sections of text, not to exceed two paragraphs, may be quoted without explicit permission provided that full credit, including $\odot$ notice, is given to the source. 
Internet Rising, Prices Falling: Measuring Inflation in a World of E-Commerce Austan D. Goolsbee and Peter J. Klenow

NBER Working Paper No. 24649

May 2018

JEL No. E31,O47

\title{
ABSTRACT
}

We use Adobe Analytics data on online transactions for millions of products in many different categories from 2014 to 2017 to shed light on how online inflation compares to overall inflation, and to gauge the magnitude of new product bias online. The Adobe data contain transaction prices and quantities purchased. We estimate that online inflation was about 1 percentage point lower than in the CPI for the same categories from 2014--2017. In addition, the rising variety of products sold online, implies roughly 2 percentage points lower inflation than in a matched model/CPI-style index.

\author{
Austan D. Goolsbee \\ Booth School of Business \\ University of Chicago \\ 5807 S. Woodlawn Avenue \\ Chicago, IL 60637 \\ and NBER \\ goolsbee@chicagobooth.edu \\ Peter J. Klenow \\ Department of Economics \\ 579 Serra Mall \\ Stanford University \\ Stanford, CA 94305-6072 \\ and NBER \\ Klenow@Stanford.edu
}




\section{Introduction}

The e-commerce share of retail spending in the U.S. has almost tripled in the last 10 years to $10 \%$ overall and more than $50 \%$ in several major categories, according to the U.S. Census Bureau (2018). See Figure 1. If online pricing is fundamentally different than traditional retail, its spread could have a rising impact on the overall Consumer Price Index (CPI) and, potentially, bias it. ${ }^{1}$

We use Adobe Analytics data on online transactions for millions of products in many different categories from 2014 to 2017 to shed light on how online inflation compares to overall inflation, and to gauge the magnitude of new product bias online. The Adobe data is similar to the Billion Prices Project of Cavallo and Rigobon (2016), which scrapes list prices from the web, but the Adobe data also contains the quantity purchased for the products in addition to prices. Table 1 provides a quick comparison between the CPI, the Adobe dataset, and the scraped data from the Billion Prices Project.

We follow two literatures. One uses detailed scanner data from grocery stores to analyze new product introductions, such as Broda and Weinstein (2010). Another studies consumer surplus from the internet and e-commerce in particular - e.g., Brynjolfsson, Hu and Smith (2003), Goolsbee and Klenow (2006), Brynjolfsson and Oh (2012), and Varian (2013).

We document 1.3 percentage points per year lower inflation online than in the CPI for the same categories. The data also show that the entry of new products and the exit of old products is extremely important for most categories of goods. The net entry of new goods during the sample implies that matched-model price indices overstate true inflation by an additional 1.5 to 2.5 percentage points per year.

\footnotetext{
${ }^{1}$ Economists have long known about the potential for new products to bias upward the inflation measured in the CPI. See Boskin et al. (1996) and, more recently, Groshen et al. (2017). Recent business press articles have argued that online commerce may be leading to growing problems in measuring inflation and complicating monetary policy decisions at the Federal Reserve, as in Cohan (2017), Torrey and Stevens (2017) and Gross (2017). Meanwhile, Gorodnichenko and Talavera (2017) document that online prices are more flexible and exhibit higher exchange rate pass-through than offline prices.
} 
Figure 1: E-commerce Share of Retail Sales

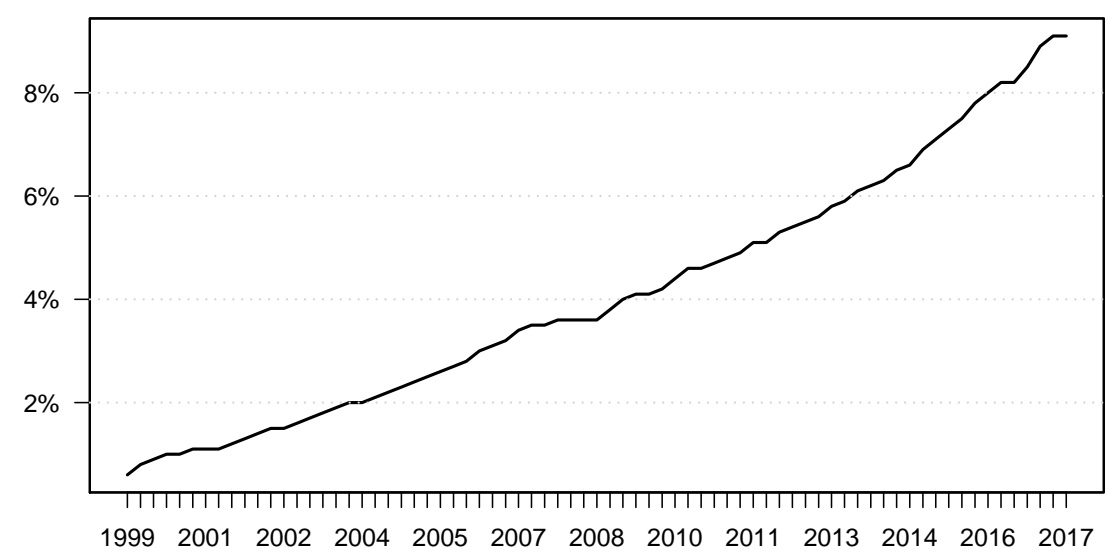

Source: U.S. Census Bureau (2018).

Table 1: Comparing the DPI to the CPI and BPP

\begin{tabular}{lccc} 
& DPI & CPI & BPP \\
\hline Quantities & Yes & No & No \\
\# of items & $2.1 \mathrm{M}$ & $140 \mathrm{~K}$ & $500 \mathrm{~K}$ \\
Offline prices & No & Yes & No \\
Long history & No & Yes & No \\
All categories & No & Yes & No \\
Merchant Identities & No & No & Yes \\
\hline
\end{tabular}

Notes: DPI $=$ Digital Price Index (Adobe), CPI $=$ Consumer Price Index from the BLS, and BPP = Billion Prices Project scraped data from Cavallo and Rigobon (2016). 


\section{Adobe Data}

Adobe Analytics provides a variety of services to e-commerce merchants who share their transaction data for Adobe to analyze. Adobe clients include 20 of the 30 largest employers in the nation and $80 \%$ of Fortune 500 retailers.

Its underlying data are the quantities and revenue from individual transactions (not including taxes or shipping costs). Product codes are merchant-specific, so our definition of a product will be the product-merchant combination. We use Adobe's data aggregated up to the monthly level: total quantities and average transaction prices for each good for each month. Adobe anonymizes the data so we cannot identify any retailers or customers.

We use a subset of the categories and merchants from the full Adobe data set. Table 2 shows the number of products in the Adobe data we use (overall and by CPI Major Group), averaged over the January 2014 to September 2017 period. It contains over 2 million products in the average month from January 2014 through September 2017, vs. about 140,000 per month in the entire CPI. There are 211 CPI categories known as Entry Level Items (ELIs), and the Adobe data covers 65 of them. The categories covered make up 19\% of the CPI relative importance weights in Bureau of Labor Statistics (2018).

Revenue in our Adobe dataset amounts to about $15 \%$ of all retail e-commerce tabulated by the U.S. Census Bureau (2018). Table 3 shows how it is distributed across CPI Major Groups. Compared to the full CPI, the dataset is definitely tilted toward tangible goods like appliances, furniture, clothing, electronics, and toys. Within some broad CPI categories, it covers only certain types of products. Within Housing, for example, the Adobe data do not include rent or owner's equivalent rent, only specific products hence we label them "Household Goods." Similarly, we refer to "Information Technology" as the goods within Education and Communication that the Adobe data covers. 
Table 2: Adobe number of products and CPI coverage

\begin{tabular}{lcc}
\hline & \# of Products & CPI Coverage \\
\hline Headline & $\mathbf{2 . 1 ~ M}$ & $\mathbf{1 9}$ \\
Food and beverages & $1 \mathrm{M}$ & 49 \\
Education and communication & $404 \mathrm{~K}$ & 9 \\
Recreation & $202 \mathrm{~K}$ & 32 \\
Apparel & $130 \mathrm{~K}$ & 100 \\
Transportation & $125 \mathrm{~K}$ & 3 \\
Housing & $92 \mathrm{~K}$ & 7 \\
Other goods and services & $92 \mathrm{~K}$ & 42 \\
Medical care & $23 \mathrm{~K}$ & 9 \\
\hline
\end{tabular}

The middle column gives the average number of products from 2014 through 2017. Headline is all CPI categories. The next rows are CPI Major Groups. The last column gives the monthly average percent of CPI category (ELI) weight covered by the Adobe data. Source: Authors' calculations using Adobe Analytics and BLS data. 
Table 3: Distribution of Adobe Revenue (\%)

\begin{tabular}{lr}
\hline Household goods & 27 \\
Apparel & 27 \\
ICT & 19 \\
Recreation goods & 14 \\
Food and beverages & 7 \\
Other goods and services & 3 \\
Transportation accessories and parts & 2 \\
Medicines and medical supplies & 1 \\
\hline
\end{tabular}

Notes: Entries are the percent of total Adobe revenue in each of the CPI Major Groups, averaged from 2014 through 2017. Source: Authors' calculations using Adobe Analytics and BLS data.

\section{DPI vs. CPI Inflation}

We construct a matched-model price index using the Adobe data, and call it the Digital Price Index (DPI) to distinguish it from the CPI. We start with price changes for overlapping products in months $t-1$ and $t$. These are products selling positive quantities in both months. We take log first differences of average unit prices. To aggregate price changes across products within an ELI, we use Tornqvist weights. These are the average spending share of the product in the ELI in months $t-1$ and $t$. The spending shares are based on Adobe data for overlapping products. ${ }^{2}$

To facilitate comparison with the CPI, we aggregate the Adobe ELI inflation rates using the CPI relative importance weights for each ELI-month. We use the same set of ELIs to construct both our comparison CPI and the DPI. In this way

\footnotetext{
${ }^{2}$ Like the BLS, we do something special for apparel. We construct a simple index of average unit prices. This is to avoid extreme deflation from fashion and seasonal cycles for clothing.
} 
Figure 2: Cumulative Inflation, DPI vs. CPI.

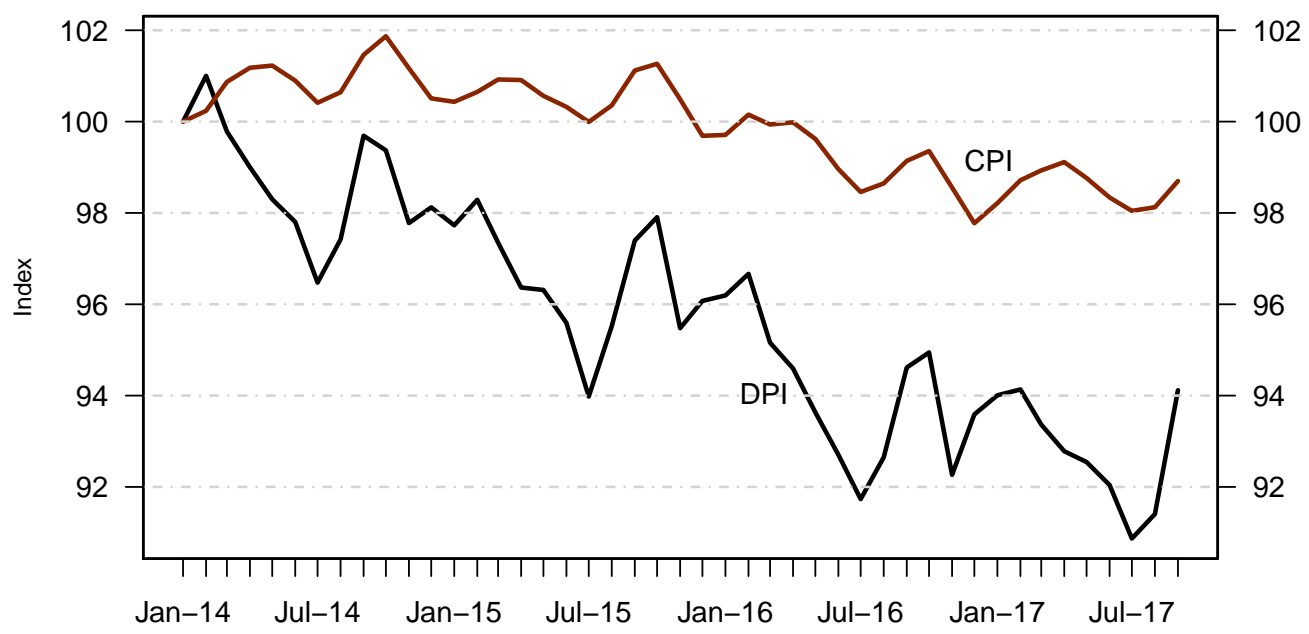

Notes: For the 65 ELIs covered by the Adobe Digital Price Index (DPI). Uses CPI relative importance weights for each ELI. Source: Authors' calculations using Adobe Analytics and BLS data.

we can rule out that differences between the two indexes arise from categories which are not covered by the DPI or the weighting of categories covered.

We plot the two indices together in Figure 2. The DPI exhibits notably more deflation over the period than the CPI for the same categories, ending up $4 \%$ lower by the end of the sample. Table 2 shows the average annual inflation rates from 2014-2017. Overall (headline) DPI inflation is 1.3 percentage points per year lower than CPI inflation for the equivalent products. Breaking out by Major Groups, inflation is lower in the DPI than in the CPI in every category other than medicine \& medical supplies.

Now, excess deflation in high frequency, chain-weighted price indices can result from oscillating prices due to recurring discounts. This phenomenon is known as "chain drift." Even if the prices and quantities revert to their starting levels, a chained price index may not revert to 1 . This has been documented in grocery store scanner data by Ivancic, Diewert and Fox (2011) and de Haan and Van der Grient (2011). 
Table 4: Average Annual Inflation

\begin{tabular}{lrr}
\hline & DPI & CPI \\
\hline Headline & $\mathbf{- 1 . 6}$ & $\mathbf{- 0 . 3}$ \\
Recreation goods & -6.1 & -3.0 \\
Household goods & -4.8 & -1.9 \\
ICT & -6.6 & -3.7 \\
Food and beverages & -0.9 & 0.3 \\
Apparel & -0.1 & 0.8 \\
Other goods and services & 0.8 & 1.7 \\
Transportation accessories and parts & -1.2 & -0.4 \\
Medicines and medical supplies & 1.3 & -0.2 \\
\hline Notes: Entries are percentage points per year in annual \\
$\begin{array}{l}\text { average inflation for 2014-2017. Source: Authors' calculation } \\
\text { using Adobe Analytics and BLS data. }\end{array}$ &
\end{tabular}

To gauge the sign and magnitude of chain drift in the Adobe data, for each year we added an artificial "13th month" in which all prices and quantities are identical to first month's prices and quantities. When then asked whether price index returns to 1 in the 13th month. As shown in Table 5, we found positive chain drift on average and in 6 of the 8 Major Groups. Chain drift was most positive for ICT and apparel items. Thus, chain drift if anything reinforces our finding that inflation is lower online than offline.

\section{Product Entry and Exit}

Because the Adobe dataset include quantities as well as prices, we are able to look at spending on entering and exit products. The CPI does not have quantities for items sold within ELIs, so it can see the frequency of products exiting but it cannot tell the market share of exiting products. And, since the 
Table 5: Chain Drift in Adobe Data

\begin{tabular}{|c|c|}
\hline Headline & 1.2 \\
\hline ICT & 5.2 \\
\hline Apparel & 2.3 \\
\hline Food and beverages & 0.9 \\
\hline Other goods and services & 0.5 \\
\hline Recreation goods & 0.3 \\
\hline Transportation accessories and parts & 0.2 \\
\hline Medicines and medical supplies & -0.2 \\
\hline Household goods & -0.7 \\
\hline
\end{tabular}

BLS samples only a small fraction of products at a given merchant, it cannot assess the frequency of product entry within merchants, much less the market share of entrants. The AC Nielsen scanner dataset also contains quantities sold, but this dataset is heavily tilted toward food and beverages in grocery stores - see Kaplan and Schulhofer-Wohl (2017). The Adobe data allow us to quantify the importance of new varieties outside of grocery stores.

We classify a product as new if the product-merchant combination did not exist in the data in the previous calendar year. Analogously, we classify a product as exiting if it does not appear in the following calendar year. We present the entry and exit rates of products by category, weighting by sales of each product in Table $6 .^{3}$ In apparel, fashion and seasonal cycles depress sales of outgoing products and inflate sales of new products. We therefore report results with and without apparel.

\footnotetext{
${ }^{3}$ We weight by the average monthly sales of a product during the calendar year across the months the product was available.
} 
Table 6: Adobe Product Entry and Exit Rates

\begin{tabular}{lcc}
\hline & Entry & Exit \\
\hline Headline & $\mathbf{5 1 . 4}$ & $\mathbf{2 4 . 3}$ \\
Headline ex. Apparel & $\mathbf{4 3 . 7}$ & $\mathbf{2 1 . 9}$ \\
Apparel & 70.8 & 30.3 \\
Recreation goods & 61.1 & 20.7 \\
ICT & 60.8 & 31.7 \\
Other goods and services & 49.9 & 13.4 \\
Household goods & 30.5 & 19.0 \\
Transportation accessories and parts & 24.6 & 16.9 \\
Food and beverages & 15.7 & 9.2 \\
Medicines and medical supplies & 11.1 & 7.6 \\
\hline
\end{tabular}

Notes: We sales-weight within ELIs, and use CPI relative importance weights across ELIs. Entries are average \% points over 2014-2015 and 2015-2016. Source: Authors' calculation using Adobe Analytics and BLS data. 
As shown in Table 6, roughly half of online sales are on products that did not exist in the previous year. Even without apparel, the figure is $44 \%$. Entry rates are particularly high for ICT products and for recreational items such as toys. Products that disappear, meanwhile, totaled about $24 \%$ of sales before they left the market (22\% excluding apparel). Note that, if all that was happening in the data was relabeling of the same products each year, then we would expect both entry and exit rates to be inflated by equal amounts. Such relabeling cannot explain the high share of entering relative to exiting products. Product entry and exit rates covary positively across the Major Groups.

The food and beverage category shows much less dynamism than other categories. Entry and exit rates for these categories are less than half that for all Adobe products (even excluding apparel). Thus previous studies finding substantial new product bias in grocery stores, such as Broda and Weinstein (2010), may have actually understated the importance of new products. ${ }^{4}$

We close this section by asking whether entry and exit rates vary with a product's price or revenue. To the best of our knowledge, little is known about this question empirically, despite the prominent role of new products in growth theory. ${ }^{5}$ Figure 3 shows that entry rates are higher for high price products. This is consistent with products entering with above-average prices, as has been documented in the CPI for apparel, electronics and appliances by Bils (2009). Entry rates are lower for high revenue products, perhaps suggesting it is harder to create high quality products and/or it takes time for products to accumulate sales as in Hottman, Redding and Weinstein (2016).

Figure 3 shows that exit rates are higher for high price products. This is more surprising, as the aforementioned studies found steep price discounts preceding product exit for apparel and electronics. Exit rates are lower for higher revenue products. This could be because such products are harder to

\footnotetext{
${ }^{4}$ Bils and Klenow (2004) report a markedly lower exit rate for food than for other CPI items.

${ }^{5}$ Classic references include Romer (1990) for expanding varieties, and Aghion and Howitt (1992) plus Klette and Kortum (2004) for rising quality through creative destruction. See Acemoglu (2008) for a textbook treatment.
} 
creatively destroy by competitors, as hypothesized by Garcia-Macia, Hsieh and Klenow (2018). It lends support to the idea that firms can escape from competition by innovating as in Aghion et al. (2005).

\section{The Impact of New Products on Inflation}

Feenstra (1994) showed that a direct way to gauge the importance of new products in a CES framework is to look at the growth rate of overall spending in a category minus the growth rate of spending for products that exist in both time periods. The higher this net growth rate, the lower the true inflation rate relative to the matched model inflation rate. As shown in Table 3, entering products do tend to have significantly bigger market shares than outgoing products in the Adobe data, even outside apparel. ${ }^{6}$ Feenstra (1994) showed that the reduction in true inflation equals the net growth in spending on new varieties times $1 /(\sigma-1)$, where $\sigma$ is the elasticity of substitution between varieties. We use a baseline value of $\sigma=4$ based on Hottman, Redding and Weinstein (2016). We also consider a higher value of $\sigma=6$ for robustness - a more conservative value given new varieties are less valuable if they are closer substitutes for existing varieties.

Table 7 presents estimates of new goods bias in the Adobe online data. Even excluding apparel, the arrival of new goods is equivalent to 1.5 to 2.5 percentage points lower inflation than what a matched-model would indicate. ${ }^{7}$ This is much higher than the $0.6 \%$ per year new product bias estimated by the Boskin Commission, though that was for the CPI as a whole. The Adobe data may cover items with larger-than-average new goods bias. Outside apparel, new goods bias looks largest for recreation and ICT products, and lowest for medicine and food.

\footnotetext{
${ }^{6}$ This should capture improvements in product quality in addition to brand new types of products, because both are associated with new product ID codes in the Adobe data.

${ }^{7}$ We exclude apparel because incoming items may sell a lot more than outgoing items purely due to seasonal/fashion cycles.
} 
Figure 3: Entry rate by product revenue and price

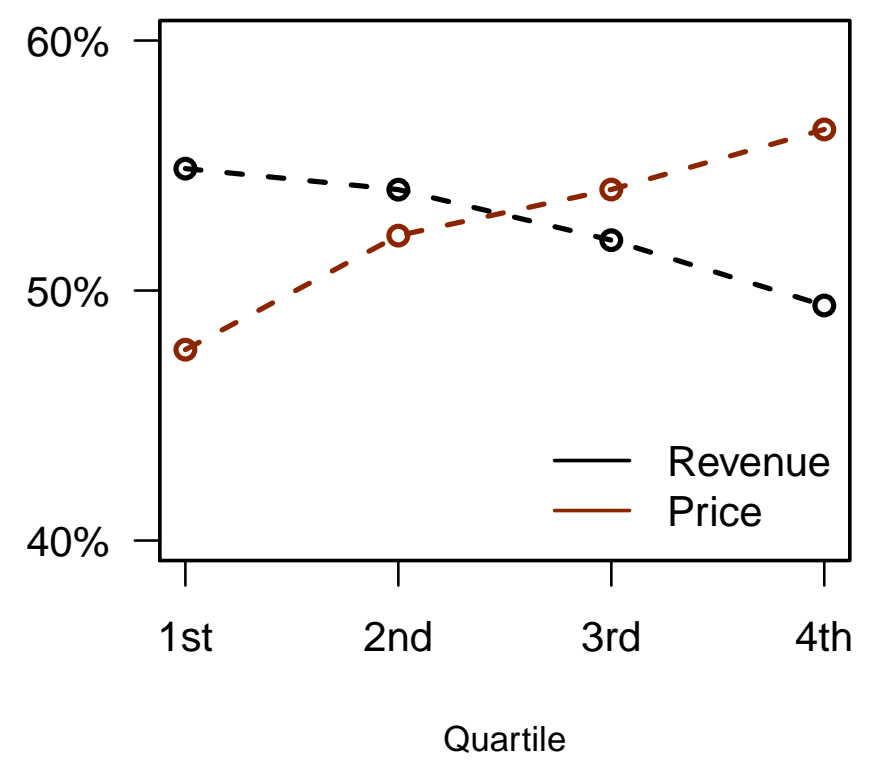

Notes: Entry rates are for 2015-2016. Products are sorted into quartiles by revenue or price within ELIs. Source: Authors' calculation using Adobe data.

Figure 4: Exit rate by product revenue and price

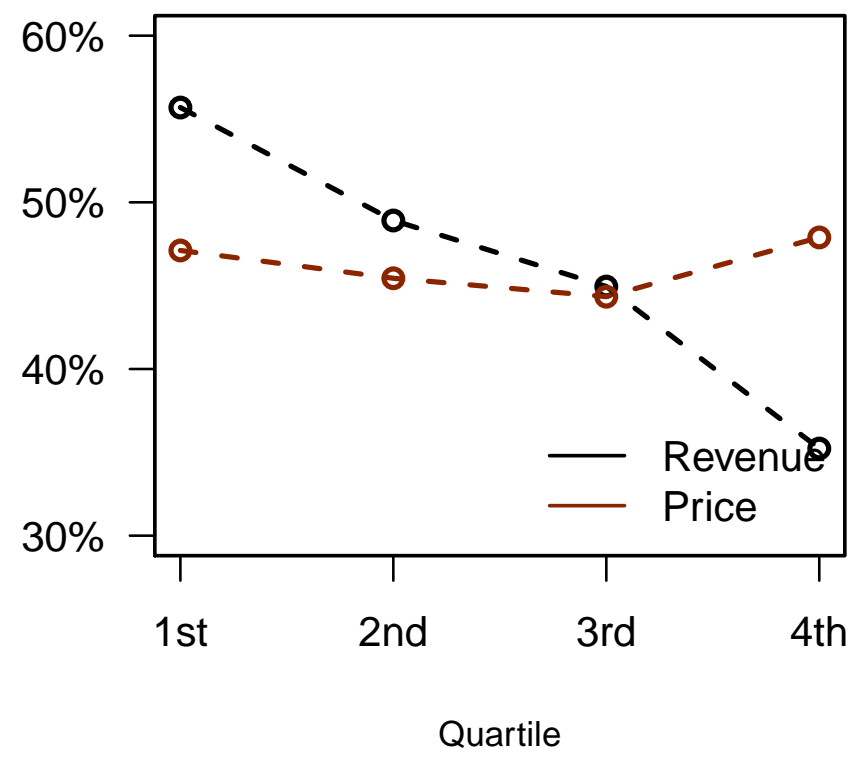

Notes: Exit rates are for 2015-2016. Products are sorted into quartiles by revenue or price within ELIs. Source: Authors' calculation using Adobe data. 
The vital role for new goods in the Adobe online data calls for more research on new varieties in traditional retail, preferably outside of just the items with UPC codes that are mostly confined to food, beverages, and drugstore items. ${ }^{8}$ If offline sales are similar to online sales, as suggested by Cavallo (2017), new products may be even more important than previously thought.

Table 7: New Goods Bias Based on the Adobe Data

\begin{tabular}{lcc}
\hline & $\sigma=4$ & $\sigma=6$ \\
\hline Headline & $\mathbf{3 . 5}$ & $\mathbf{2 . 1}$ \\
Headline ex. Apparel & $\mathbf{2 . 5}$ & $\mathbf{1 . 5}$ \\
Apparel & 7.3 & 4.4 \\
Other goods and services & 5.9 & 3.9 \\
Recreation goods & 5.4 & 3.2 \\
ICT & 4.1 & 2.5 \\
Household goods & 0.9 & 0.5 \\
Transportation accessories and parts & 0.7 & 0.4 \\
Food and beverages & 0.4 & 0.2 \\
Medicines and medical supplies & 0.0 & 0.0 \\
\hline
\end{tabular}

Notes: Entries are percentage points per year, averaged over 20142015 and 2015-2016. Source: Authors' calculation using Adobe data.

\section{Conclusion}

Using a new dataset on e-commerce transactions in many categories of goods from Adobe Analytics, we calculated matched-model inflation and explored the importance of new products. Combining the two, the true Adobe DPI inflation rate - adjusted for new goods - was more than 3 percentage points per year lower than the CPI inflation rate for the same categories from 2014-2017.

\footnotetext{
${ }^{8}$ Aghion et al. (2017) study the entire nonfarm business sector, but only at the establishment level rather than at the detailed product level.
} 


\section{Appendix}

\subsection{Summary of the Computations}

We calculate inflation in the Adobe Analytics e-commerce data dataset to facilitate comparison to the CPI in the same categories. Our procedure consisted broadly in the following steps:

1. We first matched as many of Adobe's categories as possible with categories used by the CPI. After this step, we continued working only with matched data and used CPI category names, which are formally called Entry-Level items (ELIs).

2. Since the CPI is computed on a monthly basis, we aggregated the daily Adobe data on revenue and quantities by month for each product. We computed the average price for product $i$ in category (ELI) $j$ by:

$$
p_{i, j, t}=\frac{\sum^{30} R_{i, j}}{\sum^{30} q_{i, j}}
$$

where from now on $\underline{t \text { refers to the month. }}$

3. For our baseline we do not trim the data at all. As a robustness check, we gauge the effect of trimming on the price level. As shown in Table A1, trimming on the price level has little effect on Adobe inflation rates.

4. Next, to compute the price index for every ELI at a given month, we first find the products which were sold both in the last and present month (adjacent products).

5. Again, our baseline does not trim at all. But Table Al shows robustness to trimming on extreme price changes within ELI's. 
6. For each ELI we then compute the price index for ELI $j$ for a given month by using a geometric average of "price relatives":

$$
\Pi_{j, t}=\prod_{i \in j}\left(\frac{p_{i, j, t}}{p_{i, j, t-1}}\right)^{w_{i, j, t}}
$$

where $w_{i, j, t}=\frac{v_{i, j, t-1}+v_{i, j, t}}{2}$ and $v_{i, j, t}=\frac{p_{i, j, t} q_{i, j, t}}{\sum_{i} p_{i, j, t} q_{i, j, t}}$.

7. We then aggregate the ELI indices using monthly cPI relative importance weights to arrive at our Digital Price Index (DPI):

$$
\Pi_{t}=\sum_{j} W_{j, t-1} \Pi_{j, t}
$$

where the $W_{j, t-1}$ are the CPI weights for each ELI-month. ${ }^{9}$

8. We follow the BLS and do something special for apparel. Apparel prices exhibit a sawtooth pattern over seasonal and fashion cycles. We compute the average unit price for every clothing ELI, rather than create a matchedmodel index which would exhibit sharp deflation.

Table A1: Robustness to Trimming

$2014 \quad 2015 \quad 2016 \quad 2017$

Trim $=0 /$ Level trim $=0$

\begin{tabular}{lllll}
\hline Headline & -2.17 & -1.58 & -2.36 & 0.20 \\
Headline ex Apparel & -2.70 & -0.82 & -1.17 & 1.46 \\
\hline
\end{tabular}

Trim $=0 /$ Level trim $=0.01$

\footnotetext{
${ }^{9}$ https://www.bls.gov/cpi/tables/relative-importance/home.htm
} 


\begin{tabular}{|c|c|c|c|c|}
\hline Headline & -2.80 & -1.52 & -1.99 & 0.09 \\
\hline Headline ex Apparel & -3.19 & -1.00 & -0.95 & 1.49 \\
\hline & \multicolumn{4}{|c|}{ Trim $=0 /$ Level trim $=0.05$} \\
\hline Headline & -3.70 & -1.05 & -1.93 & 0.12 \\
\hline \multirow[t]{2}{*}{ Headline ex Apparel } & -3.40 & -0.77 & -0.69 & 1.50 \\
\hline & \multicolumn{4}{|c|}{ Trim $=0.01 /$ Level trim $=0$} \\
\hline Headline & -4.58 & -3.69 & -4.42 & -2.07 \\
\hline \multirow[t]{2}{*}{ Headline ex Apparel } & -2.10 & -0.97 & -0.51 & 1.55 \\
\hline & \multicolumn{4}{|c|}{ Trim $=0.01 /$ Level trim $=0.01$} \\
\hline Headline & -4.72 & -3.20 & -3.90 & -1.43 \\
\hline \multirow[t]{2}{*}{ Headline ex Apparel } & -2.42 & -0.84 & -0.43 & 1.58 \\
\hline & \multicolumn{4}{|c|}{ Trim $=0.01 /$ Level trim $=0.05$} \\
\hline Headline & -4.56 & -1.76 & -2.87 & -0.84 \\
\hline \multirow[t]{2}{*}{ Headline ex Apparel } & -2.81 & -0.51 & -0.43 & 1.70 \\
\hline & \multicolumn{4}{|c|}{ Trim $=0.05 /$ Level trim $=0$} \\
\hline Headline & -4.44 & -3.45 & -3.77 & -3.17 \\
\hline Headline ex Apparel & -1.31 & -0.74 & -0.19 & 1.53 \\
\hline
\end{tabular}


Trim $=0.05 /$ Level trim $=0.01$

\begin{tabular}{lcccc}
\hline Headline & -4.26 & -2.49 & -2.89 & -2.48 \\
Headline ex Apparel & -1.40 & -0.65 & -0.21 & 1.61 \\
\hline
\end{tabular}

Trim $=0.05 /$ Level trim $=0.05$

Headline

Headline ex Apparel
$-3.21 \quad-0.07 \quad-1.19 \quad-1.23$

$-1.55 \quad-0.46 \quad-0.23 \quad 1.70$

\subsection{Matching Categories}

We were able to match 63 CPI ELIs and 2 CPI Strata to Adobe categories and aggregates of them. We will refer to these as 65 ELI's for short. Table A2 provides average annual inflation rates and other sample information for the DPI vs. CPI at the ELI level.

We can also aggregate up to the 8 CPI Major Groups, since the 65 ELI's have some coverage in all of them. Figures A1 through A8 plot the cumulative inflation rates for the DPI vs. the CPI at the Major Group level.

Figure A9 shows that revenue weighting in the DPI does not affect cumulative inflation relative to weighting each product within ELIs equally as in the CPI. Figure A10 shows that inflation would be even lower if one used Paasche or Fisher instead of Laspeyres, as we have done to facilitate comparison with the CPI. 
Figure A1: Food and Beverages

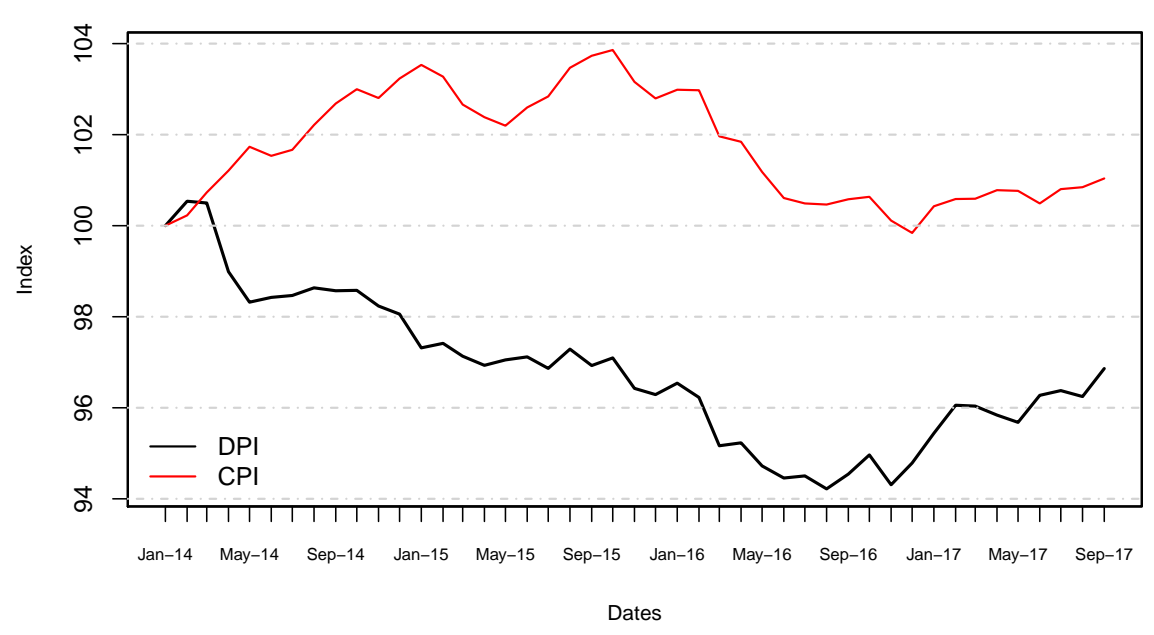

Figure A2: Household goods

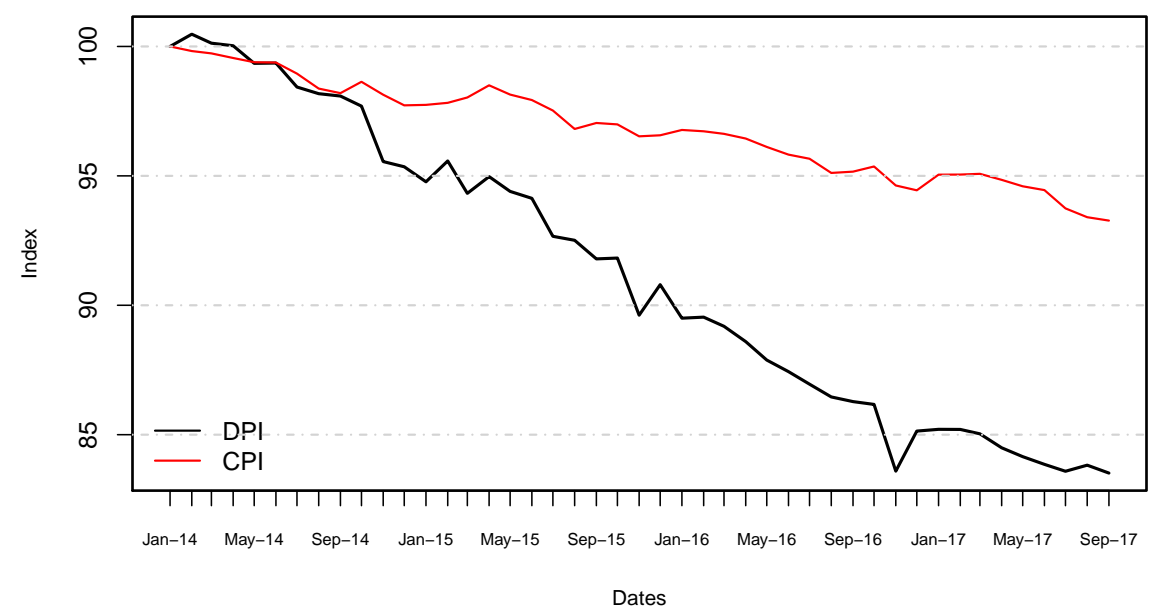


Figure A3: Apparel

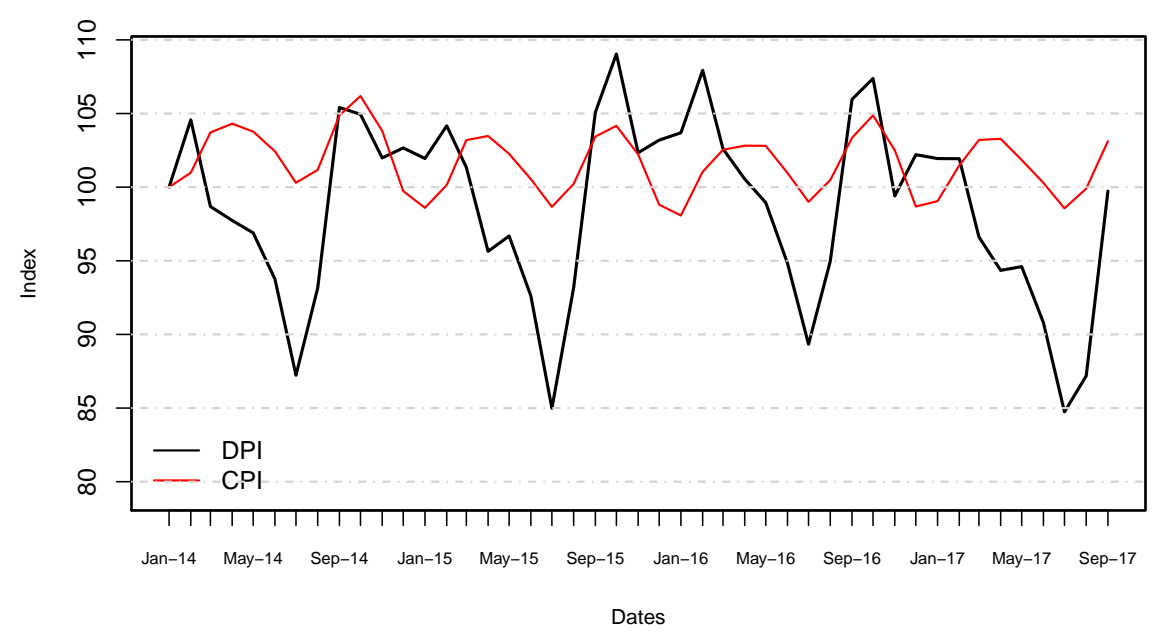

Figure A4: ICT

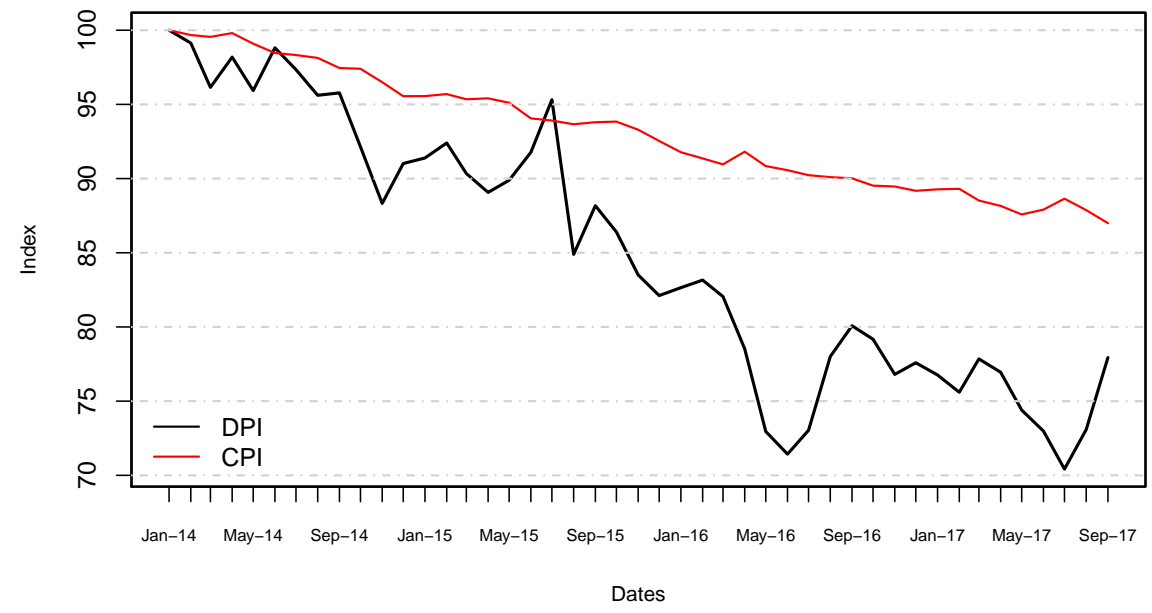


Figure A5: Medicines and medical supplies

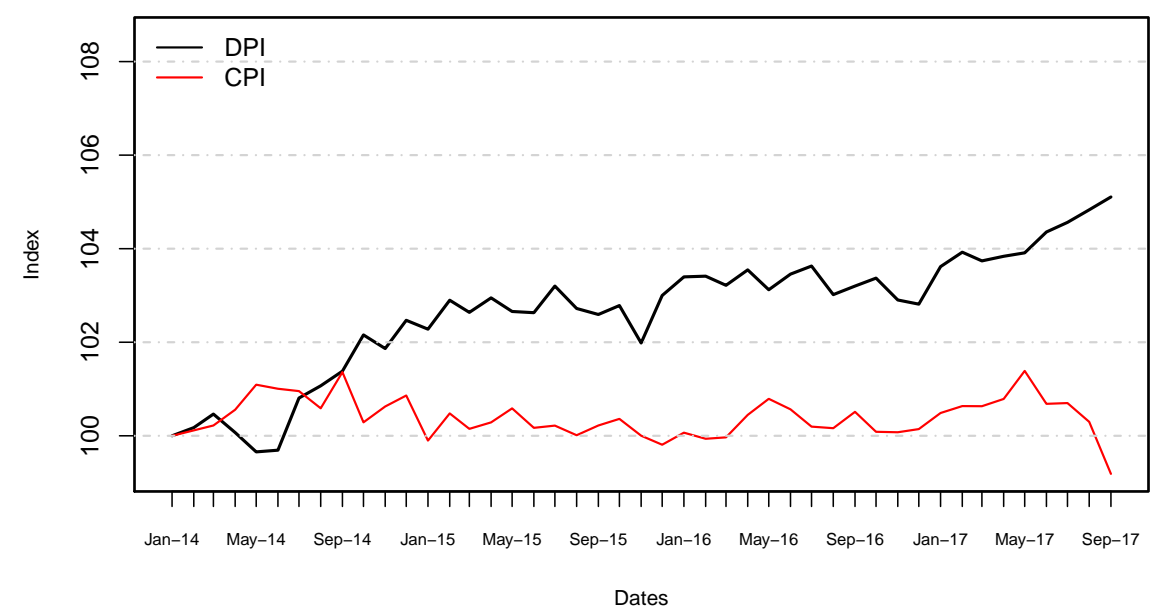

Figure A6: Transportation accessories and parts

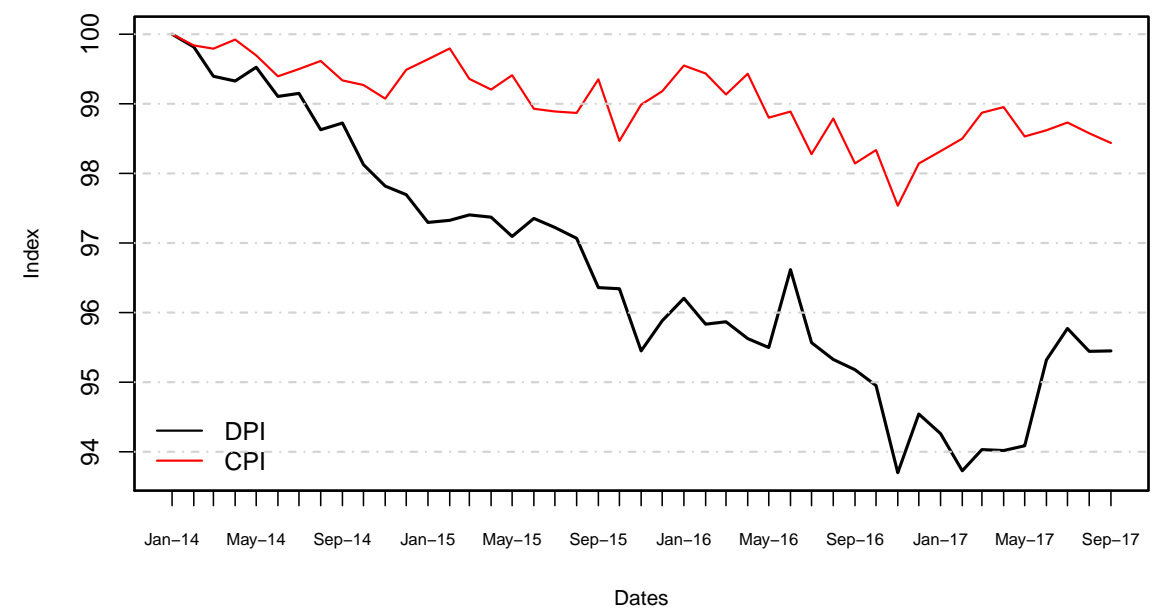


Figure A7: Recreation goods

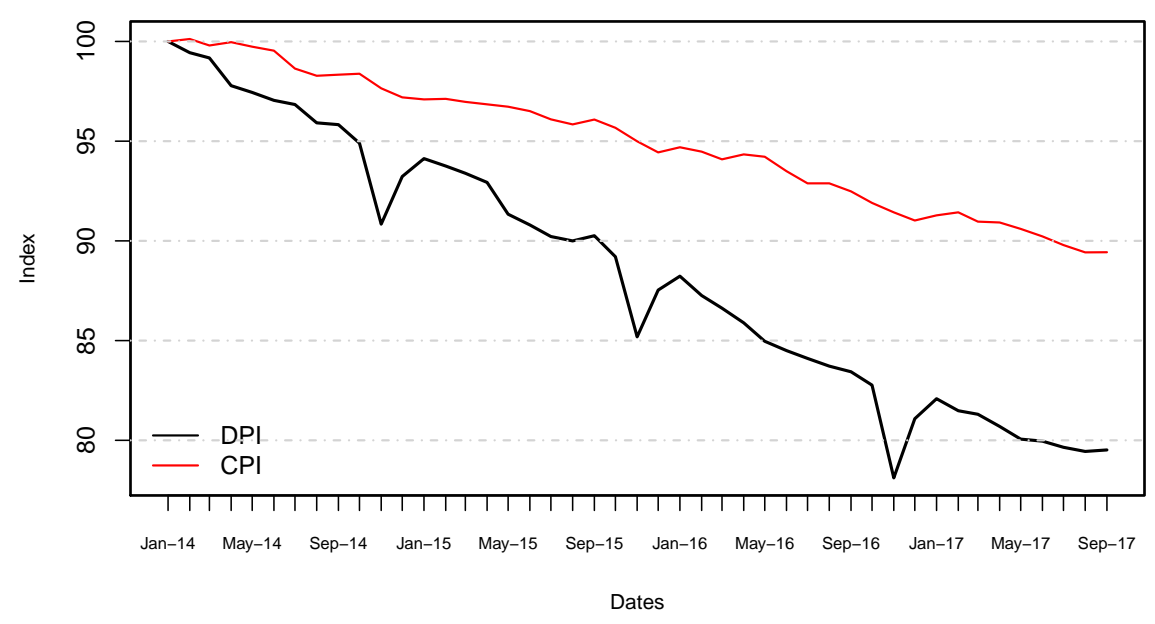

Figure A8: Other goods and services

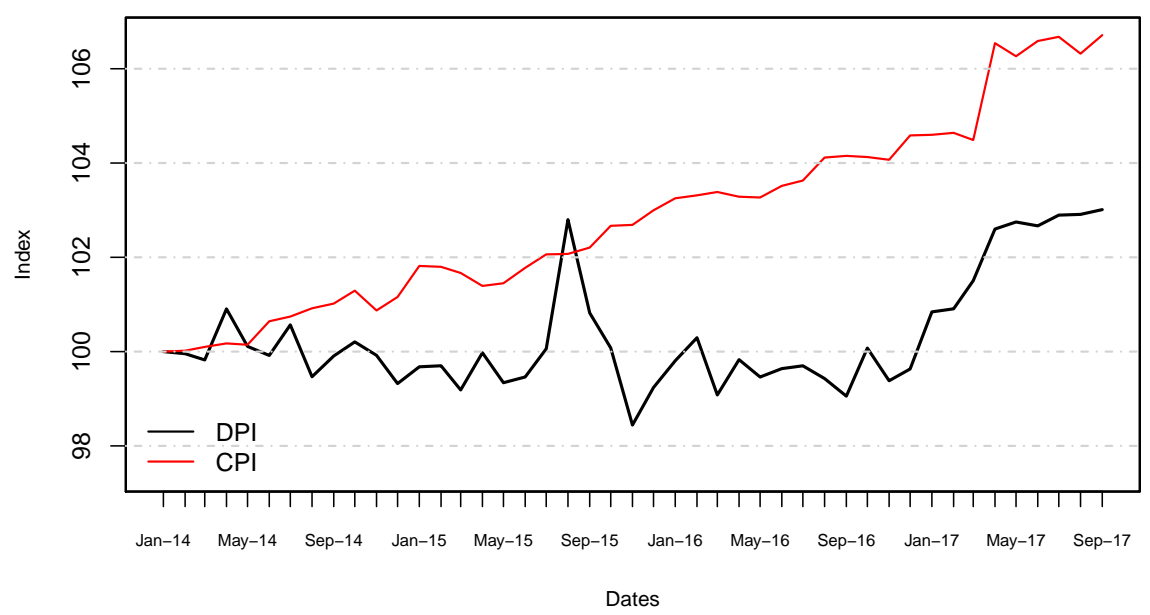


Table A2: ELI summary statistics

\begin{tabular}{|c|c|c|c|c|c|c|c|}
\hline & ELI & DPI & CPI & \# of Products & CPI Weight & Entry & Exit \\
\hline & $\begin{array}{l}\text { Beer, ale, and other malt } \\
\text { beverages at home }\end{array}$ & -0.4 & 1.1 & 4188 & 0.27 & 16 & 5 \\
\hline & Wine at home & -0.7 & -0.1 & 26619 & 0.25 & 27 & 23 \\
\hline & Distilled spirits at home & -2.4 & 0 & 2604 & 0.07 & 5 & 1 \\
\hline & Bakery products & -1 & 0.5 & 11934 & 0.74 & 20 & 7 \\
\hline & $\begin{array}{l}\text { Beverage materials including } \\
\text { coffee and tea }\end{array}$ & 0.1 & 0 & 9210 & 0.27 & 14 & 11 \\
\hline & Breakfast cereal & -0.2 & -0.6 & 3465 & 0.19 & 13 & 9 \\
\hline & Flour and prepared flour mixes & -0.5 & -1.6 & 777 & 0.05 & 19 & 4 \\
\hline & Rice, pasta, cornmeal & -1.1 & -0.7 & 4754 & 0.13 & 12 & 7 \\
\hline & Cheese and related products & -1 & 0.9 & 5479 & 0.27 & 14 & 10 \\
\hline & Ice cream and related products & -1.3 & -0.1 & 2148 & 0.12 & 24 & 10 \\
\hline & Milk & -3.8 & -2.7 & 2521 & 0.25 & 6 & 5 \\
\hline \multirow[t]{7}{*}{ Food and beverages } & $\begin{array}{l}\text { Other dairy and related } \\
\text { products }\end{array}$ & 1.8 & 0.9 & 2291 & 0.2 & 12 & 7 \\
\hline & Eggs & -6.1 & -4.5 & 706 & 0.12 & 9 & 3 \\
\hline & Fats and oils & 0.3 & 0.2 & 3744 & 0.24 & 8 & 4 \\
\hline & Fruits and vegetables & -2.1 & 0.4 & 14540 & 1.35 & 11 & 5 \\
\hline & Juices and nonalcoholic drinks & -0.2 & 0.1 & 14017 & 0.68 & 12 & 7 \\
\hline & Meats, poultry, fish, and eggs & -0.2 & 0.8 & 13962 & 1.87 & 20 & 9 \\
\hline & Sugar and sweets & -2.3 & 0.7 & 7097 & 0.29 & 15 & 10 \\
\hline & Major appliances & -5.1 & -5.8 & 14892 & 0.1 & 27 & 22 \\
\hline
\end{tabular}




\begin{tabular}{|c|c|c|c|c|c|c|}
\hline Other appliances & -6.2 & -1.4 & 15261 & 0.12 & 35 & 17 \\
\hline Other furniture & -8.9 & -2.2 & 33925 & 0.13 & 30 & 20 \\
\hline Bedroom furniture & -4.7 & -0.9 & 18674 & 0.27 & 32 & 20 \\
\hline $\begin{array}{l}\text { Living room, kitchen, and } \\
\text { dining room furniture }\end{array}$ & -5 & -1.6 & 33647 & 0.36 & 35 & 22 \\
\hline Household paper products & 0.2 & -0.1 & 1565 & 0.24 & 7 & 6 \\
\hline Household cleaning products & -1.2 & -0.8 & 15285 & 0.34 & 14 & 11 \\
\hline $\begin{array}{l}\text { Miscellaneous household } \\
\text { products }\end{array}$ & -4.5 & -0.6 & 11102 & 0.27 & 21 & 13 \\
\hline $\begin{array}{l}\text { Clocks, lamps, and decorator } \\
\text { items }\end{array}$ & -15.5 & -7 & 61068 & 0.25 & 42 & 23 \\
\hline $\begin{array}{l}\text { Nonelectric cookware and } \\
\text { tableware }\end{array}$ & -3.8 & -2.5 & 22898 & 0.07 & 33 & 20 \\
\hline $\begin{array}{l}\text { Outdoor equipment and } \\
\text { supplies }\end{array}$ & -2.6 & -1 & 11653 & 0.35 & 24 & 16 \\
\hline Tools, hardware and supplies & -3.3 & -0.6 & 29154 & 0.18 & 32 & 16 \\
\hline Window coverings & 0.2 & -3.1 & 7783 & 0.05 & 23 & 18 \\
\hline Other linens & -9.5 & -3.9 & 58445 & 0.16 & 35 & 15 \\
\hline Floor coverings & -5.1 & 0.3 & 69407 & 0.05 & 34 & 18 \\
\hline Boys' apparel & 0.7 & 0.4 & 28826 & 0.17 & 74 & 22 \\
\hline Footwear & -4.1 & 1.5 & 167897 & 0.71 & 65 & 33 \\
\hline Girls' apparel & 6.4 & 1.2 & 37444 & 0.22 & 81 & 28 \\
\hline Infants' and toddlers' apparel & -0.6 & 1.5 & 46536 & 0.14 & 81 & 33 \\
\hline Jewelry & 3.8 & 1.5 & 70874 & 0.16 & 60 & 46 \\
\hline
\end{tabular}


Apparel

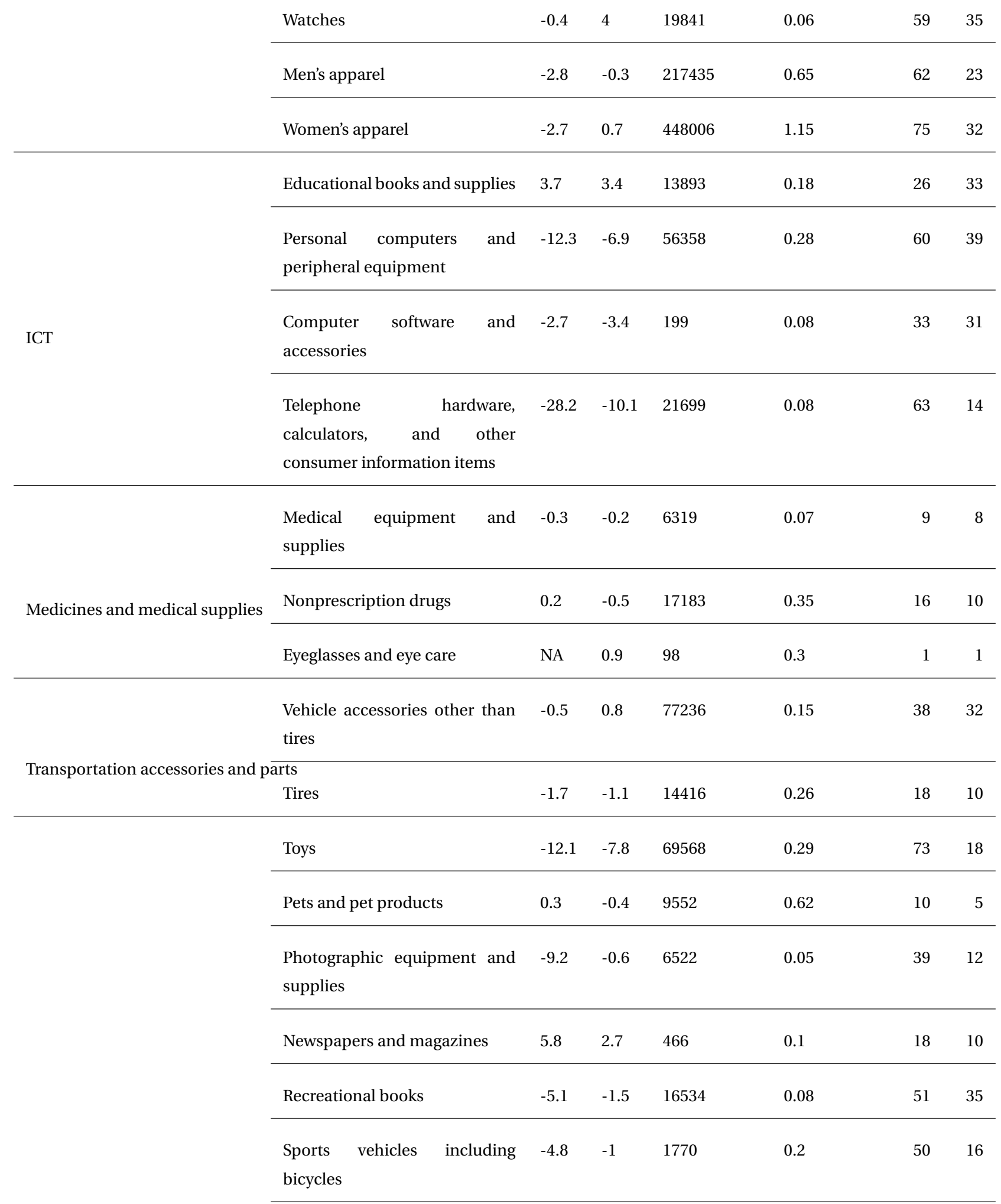




\begin{tabular}{|c|c|c|c|c|c|c|c|}
\hline \multirow[t]{5}{*}{ Recreation goods } & Sports equipment & -4.3 & -1.9 & 15074 & 0.2 & 34 & 19 \\
\hline & Audio equipment & -16.2 & -6.3 & 7421 & 0.06 & 58 & 31 \\
\hline & Other video equipment & -11 & -2.4 & 868 & 0.03 & 57 & 22 \\
\hline & Televisions & -21.1 & -16 & 4388 & 0.12 & 70 & 28 \\
\hline & $\begin{array}{l}\text { Video discs and other media, } \\
\text { including rental of video }\end{array}$ & -25.5 & -1.1 & 70218 & 0.1 & 56 & 13 \\
\hline \multirow{4}{*}{ Other goods and services } & $\begin{array}{l}\text { Hair, dental, shaving, and } \\
\text { miscellaneous personal care } \\
\text { products }\end{array}$ & -1.2 & -0.3 & 36886 & 0.37 & 29 & 13 \\
\hline & $\begin{array}{l}\text { Cosmetics, perfume, bath, nail } \\
\text { preparations and implements }\end{array}$ & -4 & -0.1 & 86014 & 0.33 & 59 & 14 \\
\hline & $\begin{array}{l}\text { Tobacco products other than } \\
\text { cigarettes }\end{array}$ & 4.5 & 2.7 & 765 & 0.05 & 3 & 2 \\
\hline & Cigarettes & 4.1 & 3.8 & 1134 & 0.63 & 11 & 5 \\
\hline
\end{tabular}

Figure A9: Cumulative Inflation, DPI vs. Unweighted DPI

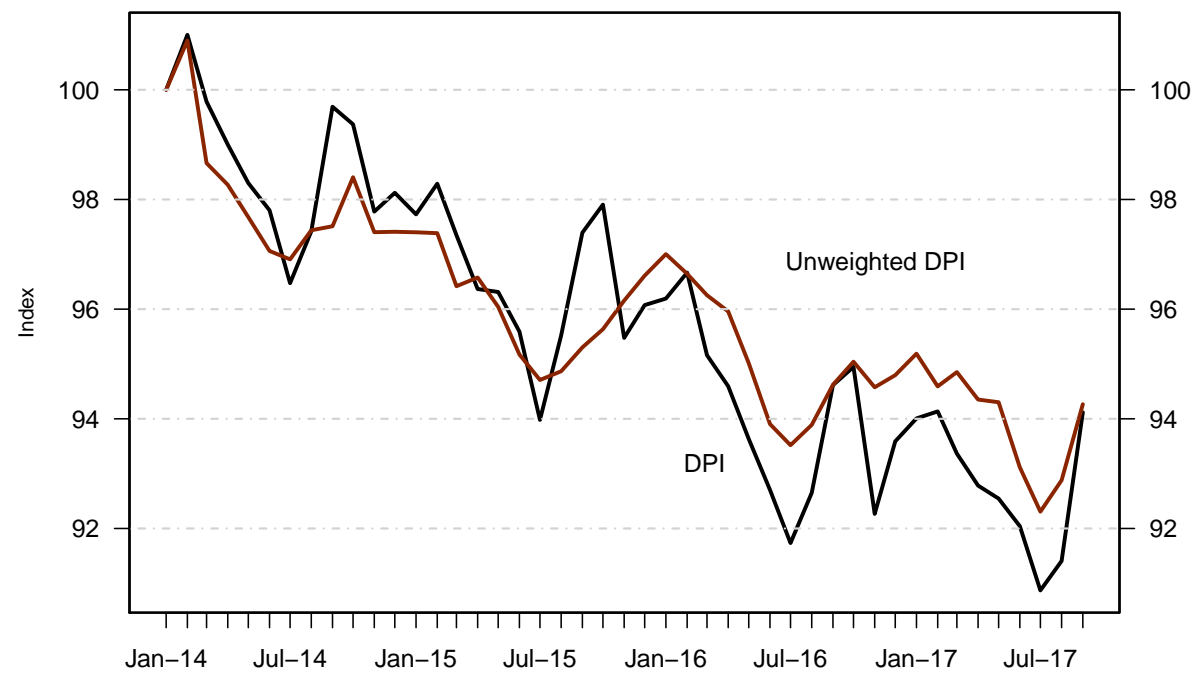


Figure A10: Cumulative Inflation, Methodology Comparison.

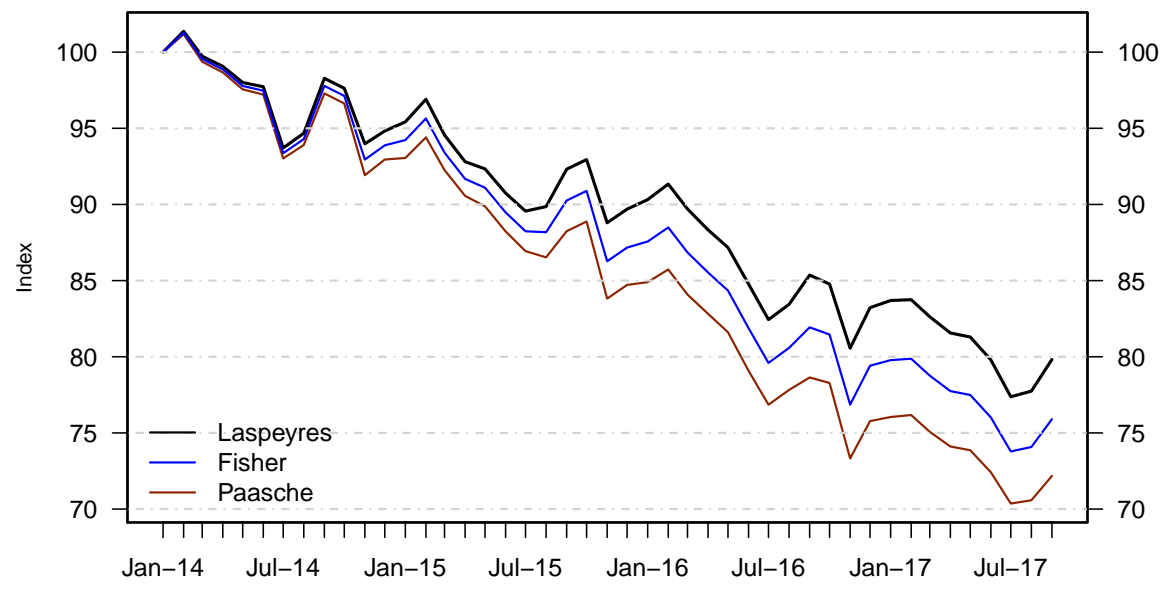

\section{References}

Acemoglu, Daron. 2008. Introduction to modern economic growth. Princeton University Press.

Aghion, P, and P Howitt. 1992. "A Model of Growth through Creative Destruction." Econometrica, 60(2).

Aghion, Philippe, Antonin Bergeaud, Timo Boppart, Peter J Klenow, and Huiyu Li. 2017. "Missing growth from creative destruction." National Bureau of Economic Research.

Aghion, Philippe, Nick Bloom, Richard Blundell, Rachel Griffith, and Peter Howitt. 2005. "Competition and innovation: An inverted-U relationship." The Quarterly Journal of Economics, 120(2): 701-728.

Bils, Mark. 2009. "Do higher prices for new goods reflect quality growth or inflation?" The Quarterly Journal of Economics, 124(2): 637-675. 
Bils, Mark, and Peter J Klenow. 2004. "Some evidence on the importance of sticky prices." Journal of political economy, 112(5): 947-985.

Boskin, Michael J, Ellen R Dulberger, Robert J Gordon, Zvi Griliches, and Dale W Jorgenson. 1996. Toward a more accurate measure of the cost of living: Final report to the Senate Finance Committee from the Advisory Commission to Study the Consumer Price Index. Advisory Commission to Study the Consumer Price Index.

Broda, Christian, and David E Weinstein. 2010. "Product creation and destruction: Evidence and price implications." The American economic review, 100(3): 691-723.

Brynjolfsson, Erik, and JooHee Oh. 2012. "The attention economy: measuring the value of free digital services on the Internet."

Brynjolfsson, Erik, Yu Hu, and Michael D Smith. 2003. "Consumer surplus in the digital economy: Estimating the value of increased product variety at online booksellers." Management Science, 49(11): 1580-1596.

Bureau of Labor Statistics. 2018. https://www.bls.gov/cpi/tables/ supplemental-files/home.htm.

Cavallo, Alberto. 2017. "Are online and offline prices similar? Evidence from large multi-channel retailers." The American Economic Review, 107(1): 283303.

Cavallo, Alberto, and Roberto Rigobon. 2016. "The billion prices project: Using online prices for measurement and research." The Journal of Economic Perspectives, 30(2): 151-178.

Cohan, Peter. 2017. "How Amazon Overpowers the Fed.” Forbes.

de Haan, Jan, and Heymerik A Van der Grient. 2011. "Eliminating chain drift in price indexes based on scanner data." Journal of Econometrics, 161(1): 36-46. 
Feenstra, Robert C. 1994. "New product varieties and the measurement of international prices." The American Economic Review, 157-177.

Garcia-Macia, Daniel, Chang-Tai Hsieh, and Peter J Klenow. 2018. "How destructive is innovation?" National Bureau of Economic Research.

Goolsbee, Austan, and Peter J Klenow. 2006. "Valuing Consumer Products by the Time Spent Using Them: An Application to the Internet." American Economic Review, 96(2): 108-113.

Gorodnichenko, Yuriy, and Oleksandr Talavera. 2017. "Price setting in online markets: Basic facts, international comparisons, and cross-border integration." American Economic Review, 107(1): 249-82.

Groshen, Erica L, Brian C Moyer, Ana M Aizcorbe, Ralph Bradley, and David M Friedman. 2017. "How Government Statistics Adjust for Potential Biases from Quality Change and New Goods in an Age of Digital Technologies: A View from the Trenches." Journal of Economic Perspectives, 31(2): 187-210.

Gross, Daniel. 2017. “How Amazon Fuels Deflation.” Strategy+Business.

Hottman, Colin J, Stephen J Redding, and David E Weinstein. 2016. "Quantifying the sources of firm heterogeneity." The Quarterly Journal of Economics, 131(3): 1291-1364.

Ivancic, Lorraine, W Erwin Diewert, and Kevin J Fox. 2011. "Scanner data, time aggregation and the construction of price indexes." Journal of Econometrics, 161(1): 24-35.

Kaplan, Greg, and Sam Schulhofer-Wohl. 2017. "Inflation at the household level." Journal of Monetary Economics, 91: 19-38.

Klette, Tor Jakob, and Samuel Kortum. 2004. "Innovating firms and aggregate innovation." Journal of political economy, 112(5): 986-1018. 
Romer, Paul M. 1990. “Endogenous technological change.” Journal of political Economy, 98(5, Part 2): S71-S102.

Torrey, Harriet, and Laura Stevens. 2017. "As the Fed Deliberates Amazon is Making it's Job More Difficult." Wall Street Journal.

U.S. Census Bureau. 2018. https://www.census.gov/retail/index.html.

Varian, Hal. 2013. "The value of the internet now and in the future." The Economist. 